\title{
Morphological and Biochemical Study of Bidens pilosa on the Effects of Extract of Urochloa ruziziensis
}

\author{
Érica Marusa Pergo Coelho ${ }^{1}$, Patrícia Aparecida Galletti ${ }^{3}$, Elizandra Aparecida Britta ${ }^{2}$, \\ Andréia Cristina Peres Rodrigues da $\operatorname{Costa}^{1} \&$ Valdir Zucareli ${ }^{1}$ \\ ${ }^{1}$ Department of Agronomic Sciences, State University of Maringá, Umuarama, Paraná, Brazil \\ ${ }^{2}$ State University of Maringá, Maringá, Paraná, Brazil \\ ${ }^{3}$ School of Agriculture Luiz de Queiroz, University of São Paulo (ESALq/USP), Piracicaba, São Paulo, Brazil \\ Correspondince: Érica Marusa Pergo Coelho, Department of Agronomic Sciences, State University of Maringá, \\ Umuarama Campus, Brazil, Estrada da Paca s/n, CEP: 87500-000, Bairro São Cristóvão, Umuarama, Paraná, \\ Brazil. Tel: 55-44-3621-9421. E-mail: profericapergo@gmail.com
}

Received: June 10, 2019

doi:10.5539/jas.v1 $1 \mathrm{n} 15 \mathrm{p} 217$
Accepted: August 4, 2019 Online Published: September 15, 2019

URL: https://doi.org/10.5539/jas.v11n15p217

\begin{abstract}
Bidens pilosa is an aggressive species that competes with crops and, in addition, has a high capacity to acquire resistance or tolerance to herbicides. Thus, the objective of the present study was to investigate the allelopathic effects of aqueous extract of Urochloa ruziziensis on germination, development, respiration, antioxidant enzymes and cells morphology of $B$. pilosa seedlings during initial growth at laboratory.The seeds were sown with water or $U$. ruziziensis extract at concentrations of 250,500 and $900 \mathrm{ppm}$, and after four days the percentage of germinated seeds, root and hypocotyl development, as well as respiration, peroxidase and catalase activity by seedlings, were analysed. The results were submitted to analysis of variance (ANOVA) and the means compared by the Tukey test and regression analysis. The cellular structures of the root with $U$. ruziziensis extract treatment $(0,500$ and $900 \mathrm{ppm})$ were also analysed by transmission electron microscopy. The application of the extract reduced the germination of the seeds. The root growth increased, however, there was a reduction in the dry matter mass at $500 \mathrm{ppm}$. Mitochondrial respiration decreased and there was an increase in the activity of the peroxidase and catalase enzymes at $500 \mathrm{ppm}$. Morphological changes in the cells were also found, mainly with this concentration. Thus, it is possible can be concluded that allelochemicals present in extract from $U$. ruziziensis have the potential to provoke oxidative stress in B. pilosa seedlings in laboratory, mainly at a concentration of $500 \mathrm{ppm}$. This oxidative stress caused alterations mainly in the energetic metabolism of this plant, being this a primordial factor for its growth and survival.
\end{abstract}

Keywords: allelopathy, weed, catalase, peroxidase, respiration, electron microscopy.

\section{Introduction}

The Bidens pilosa L. weed is an annual plant originating in South America, but is widely distributed in most regions of the world (Holm et al., 1991; Xuan \& Khanh, 2016). The seeds of this plant are widely dispersed by wind and animals, so a single plant can produce approximately 5000 seeds that can remain viable for years when buried in the soil (Xuan \& Khanh, 2016). Due to its rapid growth, this plant is found in most parts of the world and may be in both cultivated and uncultivated fields causing problems in food crops in many countries (Holm et al., 1991; Khanh et al., 2009; Mitich, 1994; Xuan \& Khanh, 2016).

In Brazil, B. pilosa occurs in most of the country and is considered to be one of the most important weeds in annual and perennial crops (Kissmann \& Groth, 1992). It is an aggressive species that competes with crops and serves as a host for pests and diseases, causing significant reductions in productivity. In addition, this species exhibits a high capacity to acquire herbicide resistance or tolerance (Kissmann, 1997). For all these reasons, there is a growing interest in developing natural alternative methods for weed control. Thousands of secondary products are produced by plants and these can be used in the process of allelopathy among living organisms, as well as providing new molecules that can be used as natural herbicides in weed control. Allelopathy is defined as the direct or indirect inhibitory or beneficial effect of a plant on another living organism through the production 
of chemical compounds that are released into the environment (Bell \& Koeppe, 1972; Gressel \& Holm, 1964; Muller, 1966).

Oliveira et al. (2019) studied the allelopathic potential of Brachiaria (Brachiaria brizantha), sunflower (Helianthus annuus) and sorghum extracts (Sorghum bicolor) on germination and initial growth of beggar ticks (Bidens pilosa). It was verified that Brachiaria and sorghum extracts showed no action on germination, but controlled the initial growth of beggar tick, being potential natural herbicides.

There are some studies that show the effect of allelochemicals present in plant extracts on other plants. Pacheco et al. (2016) studied the use of cover crops such as U. ruziziensis in no-tillage and conventional systems with soybean, corn and rice crops in the cerrado of Piauí and demonstrated significant reductions in the emergence and accumulation of weeds. Martinelli et al. (2017) studied the effect of two species of Urochloa on the Citrus and found that Urochloa as a cover is a good option for the sustainable and integrated management of weeds. Nepomuceno et al. (2017) studied the effect of U. ruziziensis when used as a vegetative cover in the cultivation of transgenic soybeans, and found that extracts collected from U. ruziziensis contained substances which can control the growth of weeds.

Oliveira et al. (2014) studied that the U. ruziziensis has shown to be specie that can be cultivated to produce straw with allelopathic potential. These effects were effective in suppressing the emergence or early growth of $E$. heterophylla and B. pilosa.

However, there are few studies that are concerned with modes of action of allelochemical. Mitochondrial respiratory metabolism is essential for the production of energy and precursors for biosynthesis of new cellular structures. An effect on respiratory metabolism could be a mode of action of natural compounds that suppress the germination and growth of weeds (Pergo et al., 2008). In order for these extracts to be used in the field, it is necessary to make tests that indicate mode of action first in the laboratory.

Thus, the objective of this study was to investigate the allelopathic effects of the aqueous extract of $U$. ruziziensis (brachiaria) on germination, development, respiration, antioxidant enzymes and cell morphology of $B$. pilosa seedlings during initial growth, at laboratory, indicating that the contribution of mitochondrial respiration to the energy metabolism of the seedlings was predominant.

\section{Materials and Methods}

\subsection{Preparation of the Aqueous Extract}

The aqueous extract of straw used was $U$. ruziziensis (brachiaria). This was planted, dried and prepared in 2017 at the Campus of the Umuarama, Paraná, Brazil. The brachiaria used for the production of the extract was planted on 15 February 2017 in a dystrophic red latosol and harvested on 1 May 2017. After collection, the plants were placed in an oven at $65^{\circ} \mathrm{C}$ and remained there for three days to achieve a quantity of stable dry matter which was then ground. This dry material $(40 \mathrm{~g})$ was mixed with $1 \mathrm{~L}$ of water and placed in an Erlenmeyer flask. The flask was placed in an orbital shaker at $200 \mathrm{rpm}$ and at a temperature of $30{ }^{\circ} \mathrm{C}$ for at least $24 \mathrm{~h}$. After that time, the solution was gassed to remove larger particles, dispensed into tubes for centrifugation at $3000 \mathrm{~g}$ for $15 \mathrm{~min}$ at $4{ }^{\circ} \mathrm{C}$. The supernatant was distributed in round-bottom flasks for lyophilization. After complete drying, the extract was removed and packed in amber flasks. Quantities extract were weighed and diluted in distilled water in order to obtain concentrations corresponding to 250,500 and $900 \mathrm{ppm}$.

\subsection{Seed Germination and Growth}

The seeds of B. pilosa L. were purchased from a commercial supplier (Cosmos Agrícola Produtos e Serviços Rurais Ltda, Brazil). Seeds were sterilised in a 1.0\% sodium hypochlorite solution. After, seeds were placed on a double sheet of germination paper in plastic germination boxes (gerbox; $110 \times 110 \mathrm{~mm}$ ), moistened with $10 \mathrm{~mL}$ of distilled water or $10 \mathrm{~mL}$ of aqueous extract of $U$. ruziziensis prepared at concentrations of 250, 500 and 900 ppm. Four replicates were used for each treatment, each replicate consisting of 50 seeds distributed in a gerbox. Experiments were repeated four times. Boxes were placed in a growth chamber with a 12/12-h light/dark photoperiod and a temperature of $30^{\circ} \mathrm{C}$.

Seeds that had germinated at four days were counted and selected for growth tests. Seedlings were removed and the primary roots and hypocotyl excised for measurement of their length and fresh matter mass. The dry matter mass of these structures were obtained after seedlings were kept in an oven with a temperature of $65{ }^{\circ} \mathrm{C}$ until reaching a constant mass. Data were expressed as centimeters or milligrams per root or hypocotyl.

In subsequent experiments, seedlings with up to four days of incubation were used, because after this period the first leaves appear showing that photosynthesis may be contributing to the energy metabolism of these seedlings. 
The experiments done in this work want to study only the contribution of mitochondrial metabolism, without the presence of photosynthetic metabolism.

\subsection{Respiration of Excised Primary Roots}

After four days of incubation, the primary roots of $B$. pilosa seedlings were removed to verify oxygen consumption measured by a clark electrode polarograph (Bracht \& Ishii-iwamoto, 2003). For each measurement, six root samples were cut into $5 \mathrm{~cm}$ segments, weighed and immediately placed in the oxygen electrode vessel with $2 \mathrm{~mL}$ nutrient solution (pH 5.8) containing $2 \mathrm{mM} \mathrm{Ca}\left(\mathrm{NO}_{3}\right)_{2}, 2 \mathrm{mM} \mathrm{KNO}_{3}, 0.43 \mathrm{mM} \mathrm{NH}_{4} \mathrm{Cl}, 0.75 \mathrm{mM}$ $\mathrm{MgSO}_{4}$ and $20 \mathrm{mM} \mathrm{NaH} \mathrm{PO}_{4}$ (Larkin, 1987). To estimate the contribution of mitochondrial cytochrome oxidase $(\mathrm{COX})$ and alternative mitochondrial oxidase (AOX), in addition to extramitochondrial oxidases, $270 \mu \mathrm{M}$ potassium cyanide $(\mathrm{KCN})$ was injected into the reaction. Oxygen uptake was monitored for $15 \mathrm{~min}$. Absorption rates were calculated from polarographic records based on an initial dissolved oxygen concentration of $240 \mu \mathrm{M}$ at $25^{\circ} \mathrm{C}$ (Estabrook, 1967) and in relation to fresh root weight.

\subsection{Peroxidase Activity}

After four days of incubation, B. pilosa primary roots or seedlings were removed to verify the presence of peroxidase activity. Primary roots or seedlings (approximately $0.2 \mathrm{~g}$ fresh weight) were weighed and transferred to a mortar where they were thoroughly mixed with $2.0 \mathrm{~mL}$ of a cold $67 \mathrm{mM} \mathrm{K}$-phosphate $(\mathrm{pH} 7.0)$ solution containing 1\% PVP. Extracts were centrifuged for $15 \mathrm{~min}$ at $3.000 \mathrm{rpm}$ and $5{ }^{\circ} \mathrm{C}$. The reaction was measured in a medium containing $25 \mathrm{mM} \mathrm{K}$-phosphate $(\mathrm{pH} 6.8), 10 \mathrm{mM} \mathrm{H}_{2} \mathrm{O}_{2}, 2.6 \mathrm{mM}$ guaiacol, and 0.1-0.4 mg protein from the enzyme extract. Tetraguaicol formation $\left(\varepsilon, 25.5 \mathrm{mM}^{-1} \mathrm{~cm}^{-1}\right)$ was measured at $470 \mathrm{~nm}$ (Pütter, 1974).

\subsection{Catalase Activity}

After four days of incubation, B. pilosa seedlings were removed to verify the presence of catalase activity. Seedlings (approximately $0.2 \mathrm{~g}$ fresh weight) were weighed and transferred to a mortar and thoroughly mixed with $2.0 \mathrm{ml}$ of a cold $67 \mathrm{mM} \mathrm{K}$-phosphate (pH 7.0) solution containing 1\% PVP. Extracts were centrifuged for $15 \mathrm{~min}$ at $3.000 \mathrm{rpm}$ and $5{ }^{\circ} \mathrm{C}$. The reaction was measured in a medium containing $67 \mathrm{mM} \mathrm{K}$-phosphate $(\mathrm{pH} 7.0)$, $10 \mathrm{mM} \mathrm{H}_{2} \mathrm{O}_{2}$, and 0.1-0.4 mg protein from the enzyme extract. The consumption of $\mathrm{H}_{2} \mathrm{O}_{2}$ was monitored at 240 $\mathrm{nm}\left(\varepsilon, 0.036 \mathrm{mM}^{-1} \mathrm{~cm}^{-1}\right)$ (Aebi, 1984).

\subsection{Electron Microscopy Studies}

After four days of incubation, B. pilosa primary roots were removed to ultrastructural analysis was performed using transmission electron microscopy (TEM). The primary roots were washed in $0.01 \mathrm{M}$ phosphate-buffered saline and prefixed in $2.5 \%$ glutaraldehyde in $0.1 \mathrm{M}$ sodium cacodylate buffer.

Then, the primary roots were postfixed in a solution containing $1 \%$ osmium tethoxide in $0.1 \mathrm{M}$ cacodylate buffer. Afterwards, they were washed in the same buffer and dehydrated in increasing concentration acetone and embedded in EPON resin.

For the ultrafine TEM sections they were stained with 5\% uranyl acetate and lead citrate and examined using a JEOL JEM 1400 transmission electron microscope.

\subsection{Statistical Analyses}

The experimental design adopted was completely randomized. The results of the evaluations were subjected to analysis of variance-ANOVA by the ' $\mathrm{F}$ ' test $(\mathrm{P} \leq 0.05)$, and the means were adjusted and submitted to the Dunnett test and regression models, and the equations were chosen based on the models. $(\mathrm{P} \leq 0.05)$ with biological logic and high $\mathrm{R}^{2}$, using the SISVAR (Ferreira, 2014).

\section{Results}

\subsection{Germination}

The germination of B. pilosa seeds decreased in the presence of the aqueous extract of $U$. ruziziensis with all tested concentrations, as can be observed in Figure 1. However, the concentration of $500 \mathrm{ppm}$ of the extract caused the lowest germination rate, $42 \%$ lower than in the controls. 


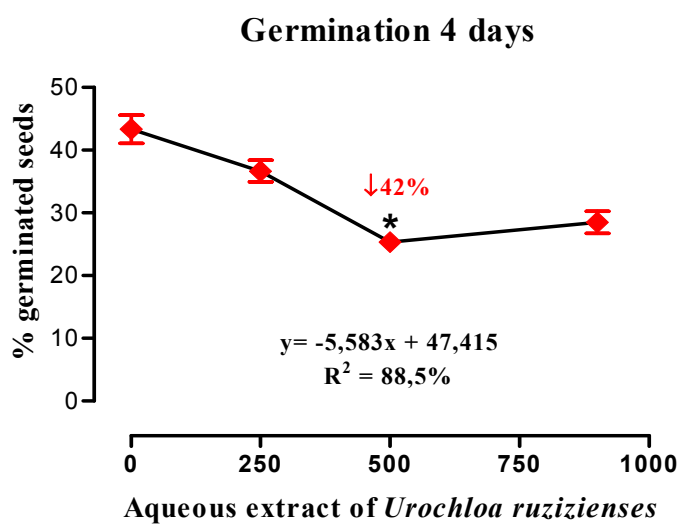

Figure 1. Germination of Bidens pilosa, on the effect of the aqueous extract of Urochloa ruziziensis in concentrations of 0,250,500 and $900 \mathrm{ppm}$, after four days of growth. * following by Dunnett's test

\subsection{Root and Hypocotyl Development}

With regard to the development of B. pilosa plants (Figures 2A-2F), the effect of the aqueous extract of $U$. ruziziensis was only evident for root growth and root dry matter mass. In the case of the variable root growth, as shown in Figure 2A, it is noted that the extract caused an increase in the root growth of B. pilosa. The increase in root growth was most accentuated with $500 \mathrm{ppm}$, which was $31 \%$ higher than the control root growth. Figure 2E shows that the dry matter mass of B. pilosa roots decreased by approximately $50 \%$ at all concentrations tested, despite the increase in root growth. This result can be explained by the image of the control root and roots grown in the presence of the extract in Figure 3, where rapid growth of the root caused by extract at $500 \mathrm{ppm}$ resulted in thinner appearance. Thus, it is understood that the cells of the root, in an attempt to recover the damage caused by the extract, grew faster and this probably hindered the normal development of the tissue. 
A, Root Growth 4 Days

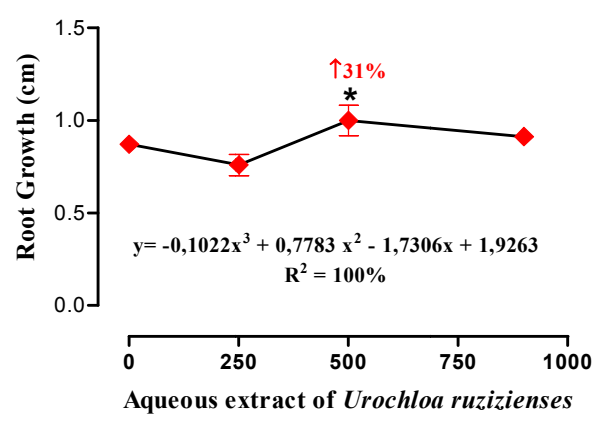

C, Root FMM 4 Days

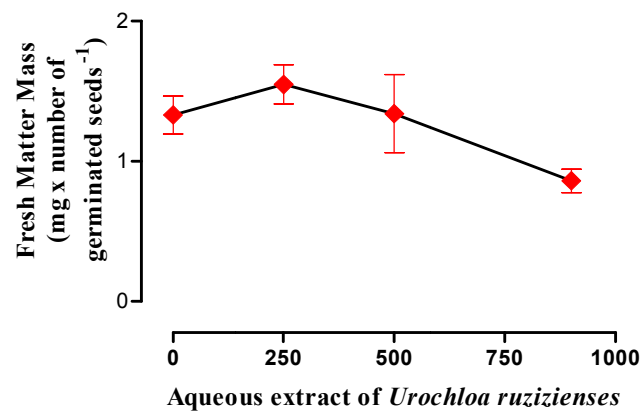

E, Root DMM 4 Days

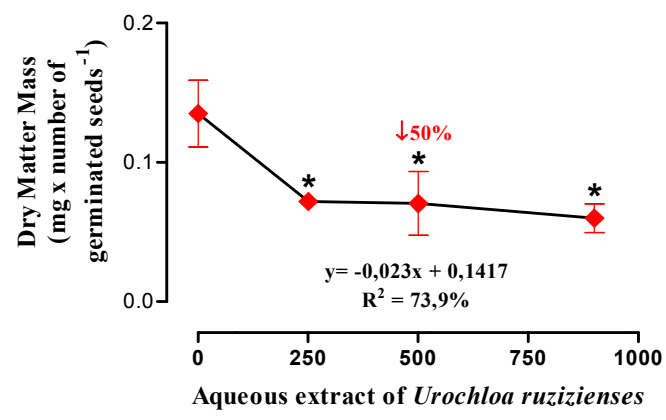

B, Hypocotyl Growth 4 Days

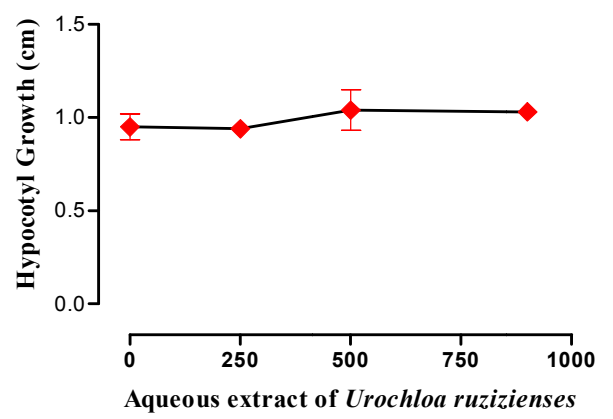

D, Hypocotyl FMM 4 Days

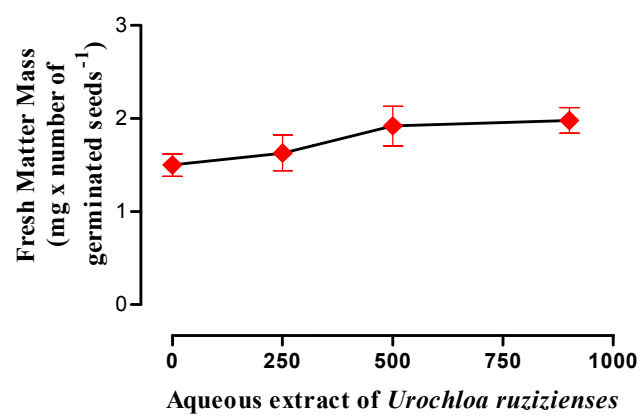

F, Hypocotyl DMM 4 Days

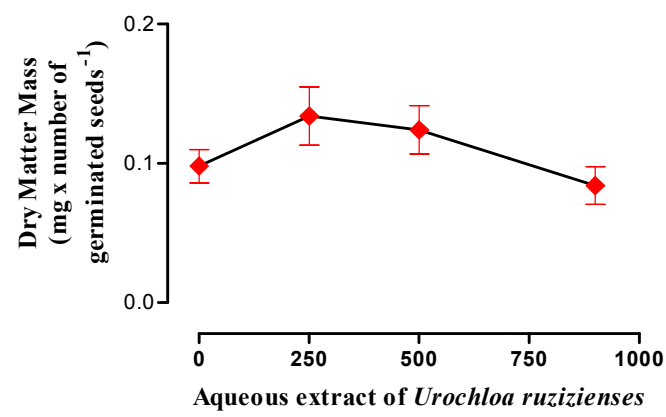

Figure 2. Primary root growth (A), hypocotyl growth (B), root fresh matter mass (C), hypocotyl fresh matter mass (D), root dry matter mass (E) and hypocotyls dry matter mass (F) of Bidens pilosa, on the effect of the aqueous extract of Urochloa ruziziensis in concentrations of 0,250,500 and $900 \mathrm{ppm}$, after four days of growth.

* following by Dunnett's test

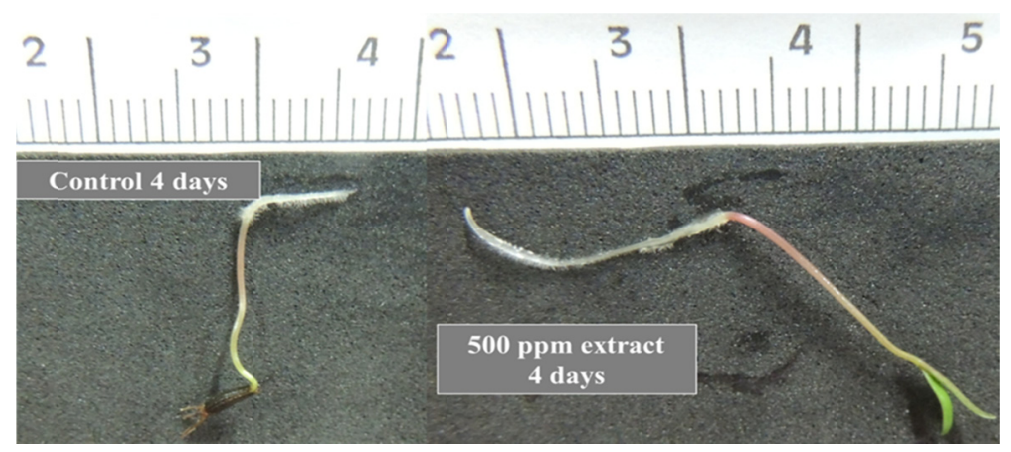

Figure 3. Images showing the morphological appearance of root of B. pilosa grown in the presence of water (control) and root grown in the presence of the aqueous extract of Urochloa ruziziensis in the concentration of $500 \mathrm{ppm}$, after four days of growth 


\subsection{Respiration Root}

In Figure 4, it can be observed that the respiration in the roots of B. pilosa seedlings also suffered changes in the presence of the aqueous extract of $U$. ruziziensis. Total tissue respiration, which is the sum of respiration that is sensitive to $\mathrm{KCN}$ and insensitive to $\mathrm{KCN}$, decreased significantly in a dose dependent manner; up to $35 \%$ and $44 \%$ inhibition occurred at concentrations of 500 and $900 \mathrm{ppm}$, respectively. The KCN-sensitive respiration, corresponding to cytochrome oxidase respiration of the mitochondria, showed the same behaviour as total respiration, except with a concentration of $500 \mathrm{ppm}$ where $\mathrm{KCN}$-sensitive respiration was higher than with other concentrations in relation to the control. The $\mathrm{KCN}$-insensitive respiration, corresponding to the respiration involving alternative oxidase and extramitochondrial enzymes, also decreased in the presence of the extract. It was observed that at $500 \mathrm{ppm}$ the lowest value for $\mathrm{KCN}$-insensitive respiration occurred, reaching $68 \%$ inhibition and showing a great change in energy metabolism of B. pilosa seedling roots. Thus, in comparing the values for total respiration, sensitive and insensitive to $\mathrm{KCN}$, we can state that the respiration that predominates in B. pilosa roots during this period of growth is almost exclusively mitochondrial via cytochrome oxidase, because the $\mathrm{KCN}$-insensitive represented only $22 \%$ of the total respiration.

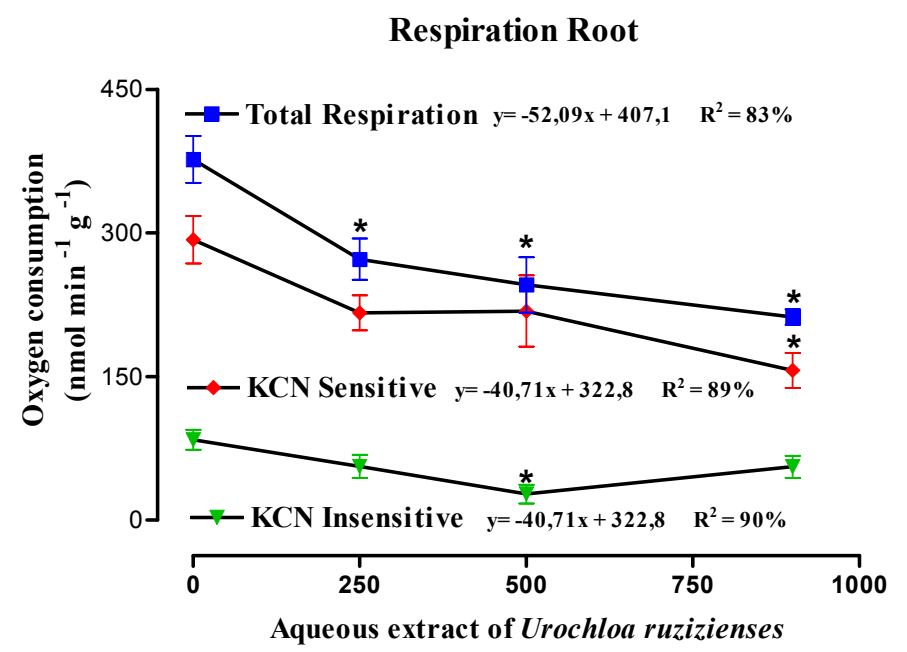

Figure 4. Respiration activity primary roots of Bidens pilosa on the effect of the aqueous extract of Urochloa ruziziensis in concentrations of $0,250,500$ and $900 \mathrm{ppm}$, after four days of growth. Total respiration: oxygen consumption in the absence of KCN; KCN Insensitive: oxygen consumption in the presence of KCN; KCN

Sensitive: difference between total respiration and KCN Insensitive. * following by Dunnett's test

\subsection{Antioxidant Enzymes}

Figure 5 shows effects on antioxidant enzymes of B. pilosa seedlings, such as peroxidase (POD) and catalase (CAT). The activity of POD (Figure 5A) in the seedlings that were grown in the presence of the aqueous extract of $U$. ruziziensis did not present a significant difference in relation to the control. Due to this, the determination of POD activity in B. pilosa seedling roots was performed again only with the $500 \mathrm{ppm}$ concentration. Thus, it is shown in Figure 5B that extract at a concentration of $500 \mathrm{ppm}$ caused a $68 \%$ increase in POD activity in relation to the control. These results are consistent with the results of CAT activity in B. pilosa seedlings, in that, as shown in Figure 5C the greatest effect of this enzyme also occurred at the concentration of $500 \mathrm{ppm}$, with a 36\% increase in the activity of this enzyme in relation to control. 

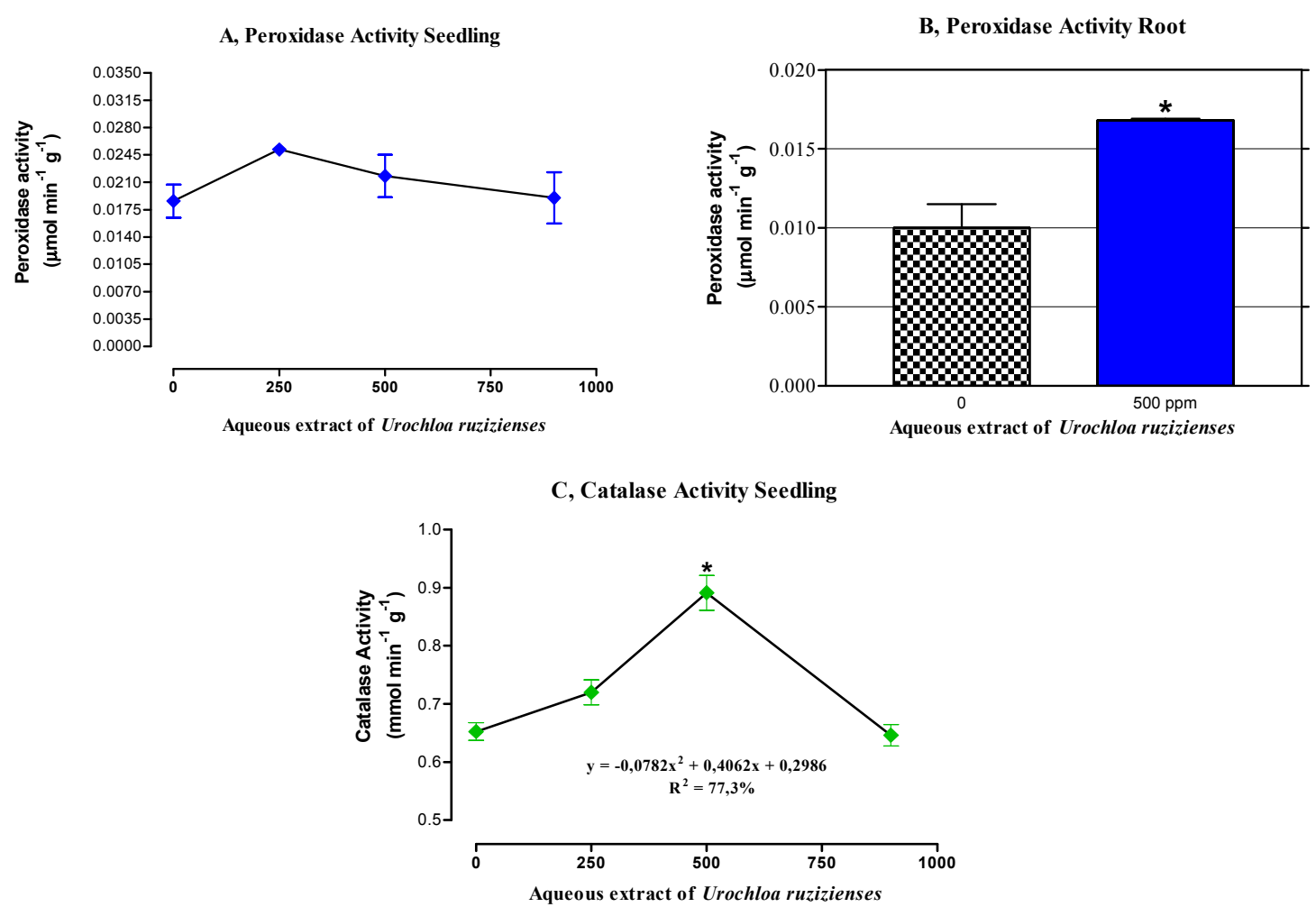

Figure 5. Peroxidase Activity seedling (A), Peroxidase Activity root (B) and Catalase activity seedling (C) of Bidens pilosa on the effect of the aqueous extract of Urochloa ruziziensis in concentrations of 0, 250,500 and 900 ppm, after four days of growth. * significant differences according to ANOVA with Dunnett's multiple range test at $5 \%$ level significance

\subsection{Images of Electron Microscopy}

Figure $6 \mathrm{a}$ and $\mathrm{b}$ show the images obtained by TEM of $B$. pilosa seedlings grown in the presence of water (control). These images show normal cells during development which corresponded to four days of growth following germination. The cytoplasm contained sufficient reserves and showed vacuoles in formation, grains of amyloplasts and the presence of mitochondria. The TEM images of roots grown in the presence of the extract at a 500ppm concentration, presented differences compared to the control images (Figure $6 \mathrm{c}$ and d). The cells are modified in that they appear to be more elongated. The cytoplasm contained large vacuoles that push the organelles to the periphery of the cell. Also, a greater number of mitochondria is observed. In Fig. 5e and f, which shows images of $B$. pilosa roots grown in the presence of the aqueous extract at a concentration of 900 ppm, no changes were observed in relation to the control images. 

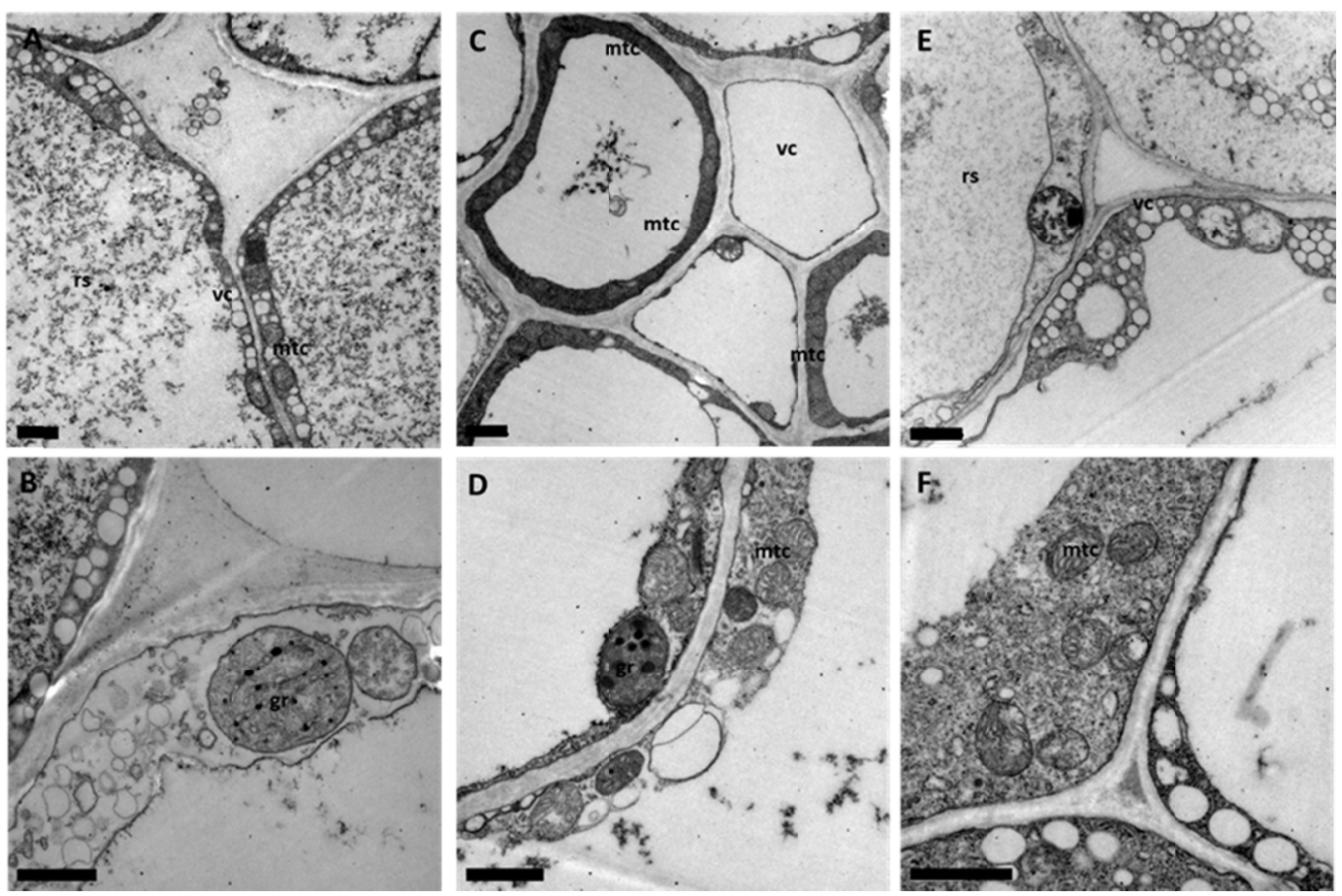

Figure 6. Electron microscopy photomicrographs of roots control $(a, b)$ and treated at the aqueous extract of Urochloa ruziziensis in concentration of $500 \mathrm{ppm}(\mathrm{c}, \mathrm{d})$ and $900 \mathrm{ppm}(\mathrm{e}, \mathrm{f})$ of Bidens pilosa on the for four days. $\mathrm{a}, \mathrm{c}$ and e: transmission electron microscopy of root showing vacuoles (vc), mitochondria (mtc) and cell reservations (rs); b, d and f: transmission electron microscopy of root showing starch granules (gr) and mitochondria $(\mathrm{mtc})$. Bars $=1 \mathrm{um}$

\section{Discussion}

In stress situations, there is an increase in the activity of antioxidant enzymes, such as peroxidase, which neutralise reactive oxygen species (ROS), such as hydrogen peroxide $\left(\mathrm{H}_{2} \mathrm{O}_{2}\right)$, as a mechanism to avoid further cell damage (Lima et al., 2002).

There are some studies that also study the antioxidant defense system of weeds, such as B. pilosa, during the early phase of growth, but no work so far has studied the defense system of this plant when submitted to the aqueous extract of $U$. ruziziensis, which makes understanding and comparison difficult.

According to Pergo and Ishii-Iwamoto (2011), and Pergo-Coelho et al. (2017), the increase in the activity of antioxidant enzymes suggests an increase in ROS generation, indicating oxidative stress caused by allelochemicals, which makes seeds and seedlings more vulnerable to dysfunction and cell death.

This stress caused by the extract was very evident in the germination that decreased, probably due to an inhibition or a delay in the germination process.

Therefore, the stress demonstrated in this study by increased POD and CAT activity with 500 ppm of the extract is probably due to activation of root growth and elongation (Figure 3). The plant probably needed more energy than normal, compromising the mitochondrial respiration, with increasing ROS and activating the defense system of antioxidant enzymes.

However, there was a cellular alteration and that this change is mainly in the energetic metabolism of the cell, so that the KCN-insensitive respiration decreased as much, about $68 \%$ in the concentration of $500 \mathrm{ppm}$ of the extract, because this represents a parallel path to the consumption of oxygen by mitochondria without the production of ATP. This again shows an effect of oxidative stress since other enzymes that help neutralize ROS and are also part of the $\mathrm{KCN}$-insensitive respiration have possibly been inhibited by the extract used.

According to Foletto et al., 2012, the waters soluble compounds of U. ruziziensis were phytotoxic to I. triloba, inducing perturbations in respiratory activity and lipid peroxidation. Although trans-aconitic acid exerted similar effects to the aqueous fraction, it is not the main compound responsible for the effects of aqueous fraction in $I$. triloba, because its content is very little in this fraction. 
According to Nepomuceno et al. (2017) studied the extracts collected from U. ruziziensis contained substances such as protodioscin and triterpenoid saponins, which can control the growth of weeds.

Protodioscin (Giancotti et al., 2015) is a bidesmosidic saponin formed by a hydrophobic moiety of the furostanol type and two sugar fragments. The structural characteristics of these compounds mean that they are readily soluble in water and, therefore, easy to be absorbed by the plant root, as shown in this work, which was the tissue most affected by the aqueous extract of $U$. ruziziensis.

It is emphasized that the experimental results obtained in the laboratory or in greenhouse are difficult to be extrapolated under field conditions, since the allelochemicals derived from the secondary metabolism of plants that are released into the environment and are transformed by the action of biotic factors (soil microflora and exudates from the roots of other competitors) and abiotic (variation of soil temperature and humidity) in order to activate or inactivate them as agents of biological control (Reigosa et al., 2013; Dayan et al., 2009; Duke, 2015).

The results are laboratory experiment, the effect of the extracts need be verified further in field test with soil media. The active compounds in extracts could be absorbed, detained, transformed and degraded in soil media, thus be weaken its bioactivity, especially the $500 \mathrm{ppm}$ level in laboratory bioassay.

\section{Conclusion}

It can be concluded that allelochemicals present in extract from $U$. ruziziensis have the potential to provoke oxidative stress in B. pilosa seedlings in laboratory, mainly at a concentration of $500 \mathrm{ppm}$. This oxidative stress caused alterations mainly in the energetic metabolism of this plant, being this a primordial factor for its growth and survival, mainly in this initial stage of development, where there is still no contribution of photosynthesis.

\section{References}

Aebi, H. (1984). Catalase in vitro. Methods in Enzymology, 105, 121-126. https://doi.org/10.1016/S0076-6879 (84)05016-3

Bell, D. T., \& Koeppe, D. E. (1972). Noncompetitive effects of giant foxtail on the growth of corn. Agronomic Journal, 64, 321-325. https://doi.org/10.2134/agronj1972.00021962006400030019x

Bracht, A., \& Ishii-Iwamoto, E. L. (2003). Métodos de Laboratório em bioquímica (1st ed.). Barueri, SP, Brazil.

Dayan, F. E; Cantrel, I. C. L., \& Duke, S. O. (2009). Natural products in crop protection. Bioorganic \& Medicinal Chemistry, 17, 4022-4034. https://doi.org/10.1016/j.bmc.2009.01.046

Duke, S. O. (2015). Proving allelopathy in crop-weed interactions. Weed Science, 63, 121-132. https://doi.org/ 10.1614/WS-D-13-00130.1

Estabrook, R. W. (1967). Mitochondrial respiratory control and polarographic measurements of ADP/O ratio. Methods of Enzymolology, 10, 41-47. https://doi.org/10.1016/0076-6879(67)10010-4

Ferreira, D. F. (2014). Sisvar: Guide for its Bootstrap procedures in multiple comparisons. Ciênc. Agrotec., 38(2), 109-112. https://doi.org/10.1590/S1413-70542014000200001

Foletto, M. P., Kagami, F., Voll, E., Kern-Cardoso, K. A., Pergo-Coelho, E. M., Rocha, M., Silva, A. A., Sarragiotto, M. H., Ishii-Iwamoto, E. L. (2012). Allelopathic effects of Brachiaria ruziziensis and aconitic acid on Ipomoea triloba weed. Allelopathy Journal, 30(1), 33-47.

Giancotti, P. R. F., Nepomuceno, M. P., Alves, P. L. C. A., \& Yamauti, M. S. (2015). Ideal desiccation periods of Urochloa ruziziensis for a no-till sunflower crop. International Journal of Plant Production, 9(1), 39-50.

Gressel, J. B., \& Holm, L. G. (1964). Chemical inhibibition of crop germination by weed seed and the nature of the inhibition by Abutilon theophrasti. Weed Research, 4, 44-53. https://doi.org/10.1111/j.1365-3180. 1964.tb00266.x

Holm, L. G., Plucknet, D. L., Pancho, J. V., \& Herberger, J. P. (1991). The world's worse weeds distribution and biology. University Press of Hawaii, Honolulu.

Khanh, T. D., Cong, L. C., Xuan, T. D., Uezato, Y., Deba, F., Toyama, T., \& Tawata, S. (2009). Allelopathic plant: 20. Hairy beggarticks (Bidens pilosa). Allelopathy Journal, 24(2), 243-254.

Kissmann, K. G. (1997). Plantas daninhas e nocivas (2nd ed.). São Bernardo do Campo: Basf, Brazil.

Kissmann, K. G., \& Groth, D. (1992). Plantas infestantes e nocivas. São Paulo: Basf Brasileira, Brazil.

Larkin, P. J. (1987). Calmodulin levels are not responsible for aluminum tolerance in wheat. Australian Journal of Plant Physiology, 14, 377-387. https://doi.org/10.1071/PP9870377 
Lima, G. P. P., Barsalobres, C., Piza, I. M. T., \& Cereda, M. P. (2002). Effect of BAP and ANA and peroxidase activity on manioc (Manihot esculenta Crantz CV 'MCOL 22') cultivated in vitro. Revista Brasileira de Agrociência, 8(2), 107-110.

Martinelli, R., Monquero, P. A., Fontanetti, A., Conceição, P. M., \& Azevedo, F. A. (2017). Ecological Mowing: An Option for Sustainable Weed Management in Young Citrus Orchards. Weed Techonology, 31, 260-268. https://doi.org/10.1017/wet.2017.3

Mitich, L. W. (1994). Beggarticks. Weed Technology, 8,172-175. https://doi.org/10.1017/S0890037X00039403

Muller, C. H. (1966). The role of chemical inhibition (allelopathy) in vegetation composition. Bull. Torrey Botany Club, 93(5), 332-351. https://doi.org/10.2307/2483447

Nepomuceno, M. P., Chinchilla, N., Varela, R. M., Molinda, J. M. G., Lacret, R., Alves, P. L. C. A., \& Macias, F. A. (2017). Chemical evidence for the effect of Urochloa ruziziensis on glyphosate-resistant soybeans. Pest Manag Science, 73, 2071-2078. https://doi.org/10.1002/ps.4578

Oliveira, J. S., Peixoto, C. P., Ledo, C. A. S., \& Almeida, A. T. (2019). Aqueous plant extracts in the control of Bidens pilosa L. Arq. Inst. Biol., 86. https://doi.org/10.1590/1808-1657000532016

Oliveira, Jr. R. S., Rios, F. A., Constantin, J., Ishii-Iwamoto, E. L., Gemelli, A., \& Martini, P. E. (2014). Grass straw mulching to suppress emergence and early growth of weeds. Planta Daninha, 32, 11-17. https://doi.org/10.1590/S0100-83582014000100002

Pacheco, L. P., Petter, F. A., Soares, L. S., Silva, R. F., \& Oliveira, J. B. S. (2016). Production systems and weed control in annual crops of the cerrado area of the State of Piauí. Revista Ciência Agronômica, 47, 500-508. https://doi.org/10.5935/1806-6690.20160060

Pergo, É. M., \& Ishii-Iwamoto, E. L. (2011). Changes in energy metabolism and antioxidant defense systems during seed germination of the weed species Ipomoea triloba $\mathrm{L}$. and the responses to allelochemicals. Journal Chemical Ecology, 37, 500-513. https://doi.org/10.1007/s10886-011-9945-0

Pergo, É. M., Abrahim, D., Silva, P. C. S., Kern, K. A., Silva, L. J., Voll, E., \& Ishii-Iwamoto, E. L. (2008). Bidens pilosa L. Exhibits High Sensitivity to Coumarin in Comparison with Three Other Weed Species. Jounal of Chemical Ecology, 34, 499-507. https://doi.org/10.1007/s10886-008-9449-8

Pergo, É. M., Barbosa, M. C., Mito, M. S., Montavanelli, G. C., Oliveira, R. S., \& Ishii-Iwamoto, E. L. (2017). The Activity of the Antioxidant Defense System of the Weed Species Senna obtusifolia L. and its Resistance to Allelochemical Stress. Journal of Chemical Ecology, 43, 725-738. https://doi.org/10.1007/ s10886-017-0865-5

Putter, J. (1974). Peroxidases. In H. U. Bergmeryer (Ed.), Methods of Enzymatic Analysis (pp. 685-690). New York: Elsevier. https://doi.org/10.1016/B978-0-12-091302-2.50033-5

Reigosa, M., Gomes, A. S., Ferreira, A. G., \& Borghetti, F. (2013). Allelopathic research in Brazil. Acta Botanica Brasílica, 27, 629-646. https://doi.org/10.1590/S0102-33062013000400001

Xuan, T. D., \& Khanh, T. D. (2016). Chemistry and pharmacology of Bidens pilosa: An overview. Journal of Pharmaceutical Investigation, 46, 91-132. https://doi.org/10.1007/s40005-016-0231-6

\section{Copyrights}

Copyright for this article is retained by the author(s), with first publication rights granted to the journal.

This is an open-access article distributed under the terms and conditions of the Creative Commons Attribution license (http://creativecommons.org/licenses/by/4.0/). 